\title{
踏切長・鳴動状態・混雑状態が踏切横断時の歩行速度に与える 影響1
}

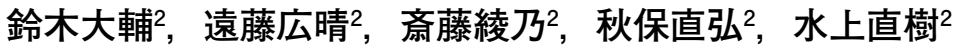

\begin{abstract}
This study aims to clarify the effects of length, warning, and congestion on the walking velocity of pedestrians at railroad crossings. Video recordings of 13,386 pedestrians were made at railroad crossings and their walking velocities were calculated. Multiple regression analyses were conducted with the mean and standard deviation of the pedestrians' walking velocity set as the objective variable. The explanatory variables in this study were the length, warning, and congestion at the railroad crossing. Among the explanatory variables that influenced the mean of walking velocity, warning of railroad crossing had the greatest influence. With all other variables being constant, the mean of walking velocity increased by $0.541 \mathrm{~m} / \mathrm{s}$ when pedestrians entered the railroad crossing after the railroad crossing rod began falling. Among the explanatory variables that influenced the standard deviation of walking velocity, the congestion had the largest influence. With all other variables being constant, the standard deviation of walking velocity decreased by $0.159 \mathrm{~m} / \mathrm{s}$ when the congestion increased by 1.0 person $/ \mathrm{m}^{2}$.
\end{abstract}

踏切長, 鳴動状態, 混雑状態が踏切横断時の歩行速度に与える影響を定量的に明らかにすることを目 的とした．踏切内の通行状況をビデオカメラで撮影し，13,386名の歩行速度を計測した。歩行速度の平 均值および標準偏差を目的変数として, 踏切長, 鳴動状態（踏切の鳴動および遮断の状態と歩行者が踏 切に進入するタイミングの関係)，混雑状態（歩行者の密度）を説明変数とした重回帰分析を行った。そ の結果，歩行速度の平均值に影響を与える要因の中で，遮断桿が降下を開始した後に進入することの影 響が最も大きかった，他の変数を一定にした場合，踏切を渡りきるまで鳴動しない状態と比較して，遮 断桿が降下を開始した後に踏切に進入すると，歩行速度の平均值は $0.541 \mathrm{~m} / \mathrm{s}$ 速くなった．また，歩行速 度の標準偏差に影響を与える要因の中で，歩行者の密度の影響が最も大きかった．他の变数を一定にし た場合，密度が 1.0 人 $/ \mathrm{m}^{2}$ 高くなると，歩行速度の標準偏差は $0.159 \mathrm{~m} / \mathrm{s}$ 小さくなった.

(キーワード : 踏切長, 鳴動状態, 混雑状態, 歩行速度, 重回帰分析)

\section{1.はじめに}

\section{1-1. 背景と目的}

踏切事故の原因究明と再発防止のために国土交通省が 設置した「高齢者等による踏切事故防止対策検討会」の 報告1) によると，2013年度の踏切事故死亡者に占める歩 行者の割合は約7割で，そのうち約4割は65歳以上の高齢 者であった。 その原因として，歩行速度が遅いことや自 動車とすれ違う際に歩行を中止してしまうこと等が挙げ られた. 高齢者の歩行速度については数多くの研究が報 告されている. 溝端2) は，1,280名の歩行速度を計測し，

1 受付：2018年7月2日 受理：2019年5月14日

2 公益財団法人鉄道総合技術研究所

Railway Technical Research Institute
36 59歳では平均 $1.24 \mathrm{~m} / \mathrm{s}$ （標準偏差 $0.23 \mathrm{~m} / \mathrm{s}$ )，75歳以 上では平均 $1.03 \mathrm{~m} / \mathrm{s}$ （標準偏差 $0.23 \mathrm{~m} / \mathrm{s}$ ) であったと報告 している。 また，Lord $5^{3)}$ は，183名の女性の歩行速度 を計測し，40歳代では平均 $1.29 \mathrm{~m} / \mathrm{s}$ （標準偏差 $0.12 \mathrm{~m} / \mathrm{s}$ ), 70〜 74歳では平均 $1.07 \mathrm{~m} / \mathrm{s}$ （標準偏差 $0.17 \mathrm{~m} / \mathrm{s}$ )，75〜 79 歳では平均 $1.01 \mathrm{~m} / \mathrm{s}$ （標準偏差 $0.19 \mathrm{~m} / \mathrm{s}$ ）であることを 示した. さらに，Bohannon ${ }^{4)}$ は，237名の歩行速度を調 査し，性別，年代別の標準歩行速度および最高歩行速度 を計測した。その結果，例えば男性の標準歩行速度にお いて 40 歳代では平均 $1.46 \mathrm{~m} / \mathrm{s}$ （標準偏差 $0.16 \mathrm{~m} / \mathrm{s}$ )，70歳 代では平均 $1.33 \mathrm{~m} / \mathrm{s}$ （標準偏差 $0.20 \mathrm{~m} / \mathrm{s}$ ) であることを示 した.このように，高歯者は他の年代より歩行速度が遅 い傾向である．踏切を安全に渡りきるためには，歩行速 度が遅いことは一つの大きな問題であり，踏切横断時の 歩行速度に影響を与える要因を知ることは，踏切の安全 性向上に極めて重要である. 
踏切での人間の行動の研究については，主に自動車ド ライバーと歩行者の報告に分けられる。まず，自動車ド ライバーについて, 佐藤ら ${ }^{5,6)}$ は, 踏切前での一旦停止義 務を解除した際，仮に先行車が踏切を超えた地点で停止 した場合にどの程度トリコ（踏切先での先行車の停止等 によるスペースの無さから自車が踏切内に停滞してしま う状況）が発生するのかを評価した。 また，松本ら7)は， 自動車ドライバーの横断直前における一旦停止の有無が 安全性に与える影響を評価した。ささらに，Tenkinkら ${ }^{8)}$ は， 踏切手前の警告灯の種類による自動車ドライバーの運転 行動の違いを調査した. Lennéら ${ }^{9)}$ は, 停止標識, 警告灯, 交通信号が設置された踏切において，自動車ドライバー の運転行動を比較した。次に，歩行者について，福田 ${ }^{10}$ は，リスクテイキング行動を生じさせる警報時間の影響 を明らかにするために，警報が鳴り始めてから渡り始め た歩行者等の多さ（横断実行率）を1時間の合計警報時 間が長い朝時間帯と合計警報時間が短い昼時間帯で比較 した. また，Lobbら ${ }^{11)}$ は，踏切における不法な横断を防 止するためのポスターや警告サインの効果を評価した. さらに，Khattakら ${ }^{12)}$ は，踏切における歩行者と自転車 の交通違反について調査した。 このように踏切における 自動車ドライバーの運転行動や歩行者のリスクテイキン グ行動等は報告されているが，踏切横断時の歩行速度に 影響を与える要因については検討されてこなかった。

筆者らは踏切における歩行速度の実態を把握するため に基礎的な検討を進めてきた。 まず，鈴木ら ${ }^{13)}$ は，東京 都内3箇所の踏切において 2,854 名の歩行者を対象に，踏 切に進入する際の踏切の鳴動状態（踏切の鳴動および遮 断の状態と歩行者が踏切に進入するタイミングの関係) が歩行速度に与える影響を調査した. その結果，鳴動後 に進入した場合は歩行速度が速く，ばらつきが大きかっ た. また，鈴木ら ${ }^{14)}$ は，東京都内3箇所の踏切に打いて 4,726名の歩行者を対象に, 踏切内の混雑状態（歩行者 の密度）が歩行速度に与える影響を調査した。その結果， 歩行者の密度が高いと歩行速度は遅かった。 これらの研 究では, 鳴動状態および混雑状態と歩行速度の関連性は 示されたものの，それらの影響の定量化には至っていない.

そこで本研究では, 踏切長, 鳴動状態, 混雑状態が踏 切横断時の歩行速度に与える影響を定量的に明らかにす ることを目的とした。

\section{1-2. 先行研究と本研究の関連}

道路交通分野での歩行速度に関する先行研究を参考 に，踏切において歩行速度に影響を与える要因につい て検討する。道路交通分野では日常の歩行速度特性の
研究が行われてきた。 交通工学ハンドブック15) による と，通勤中の歩行速度の平均值は $1.54 \mathrm{~m} / \mathrm{s}$ （標準偏差 $0.18 \mathrm{~m} / \mathrm{s}$ ), 買い物中の歩行速度の平均值は $1.06 \mathrm{~m} / \mathrm{s}$ （標 準偏差 $0.19 \mathrm{~m} / \mathrm{s}$ ) である. また，Transportation and traffic engineering handbook ${ }^{16)}$ によると，成人の歩行速度の平均 值は約 $1.4 \mathrm{~m} / \mathrm{s}$ である.

歩行者の横断行動を考慮した信号現示方式や横断速度 に応じた青信号点灯時間の設定について検討するために， 横断歩道における歩行速度特性に関する研究が数多く報 告されている．まず，横断歩道長の影響について，斉藤 ら 17) は，東京都内の35箇所の横断歩道において 12,668 名 の歩行者を対象に歩行速度を計測した。各横断歩道にお ける平均歩行速度を目的変数とし，横断歩道長を説明変 数とした回帰分析の結果，横断歩道長が $5 \mathrm{~m}$ 長くなると 平均歩行速度は約 $0.05 \mathrm{~m} / \mathrm{s}$ 速くなることを示した.

次に，青信号の点滅の影響について，張ら ${ }^{18)}$ は，名古 屋市内8箇所の横断歩道において 6,821 名の歩行者を対象 に歩行速度モデルを構築し，信号現示が歩行速度分布に 及ぼす影響を調査した。その結果，青信号点滅後に横断 を開始した歩行者は青信号点灯中に横断を開始した歩行 者より速度が速く，そのばらつきが大きかった。また， 矢野19) は，東京都内3箇所の横断歩道において4,333名の 歩行者を対象に，横断途中で信号が青信号点滅や赤信号 に切り替わった場合の横断歩行者の速度変化について調 査した。その結果，残りの横断距離が長くない場合，横 断途中で信号が青信号点滅や赤信号に切り替わっても歩 行速度はあまり上昇しなかった。一方で，信号切り替わ り後の残りの横断距離が $20 \mathrm{~m}$ を超えるような長い場合, 歩行速度は上昇する傾向であった。同様に，矢野20) は， 東京都内5箇所の横断歩道において2,686名の歩行者を対 象に，青信号点灯が始まってからの横断タイミングに着 目し，横断歩道長と横断速度の関係を調査した。その結 果，横断歩道が長く横断開始タイミングが遅い歩行者ほ ど横断速度が高い傾向であった。さらに，Lamら ${ }^{21)}$ は, 香港の都市部において 1,383 名の歩行者を対象に，信号 と歩行速度の関係を調査した。その結果，信号のある横 断歩道では信号のない横断歩道と比較して歩行速度が速 く，特に青信号点滅後は速く歩くことを示した.

最後に，歩行者の密度の影響については，歩道や地 下道での研究が報告されている。毛利ら ${ }^{22)}$ は，大阪市 内6箇所の歩道および地下道において，通勤時に任意抽 出した50名の歩行者を対象に，歩行者密度と歩行速度 の関係を調查した。歩行速度を目的変数とし，歩行者 密度を説明変数とする回帰分析の結果，歩行者密度が 1.5 人 $/ \mathrm{m}^{2}$ 未満の場合，密度が 1.0 人 $/ \mathrm{m}^{2}$ 増えると歩行速度 
が $0.204 \mathrm{~m} / \mathrm{s}$ 羊くなること, 密度が 1.5 人 $/ \mathrm{m}^{2}$ 以上になると， 歩行速度はいったん急激に低下寸るが，その後はまた緩 やかに低下していくことを示した．また，高宮ら23) は， 歩行者交通量の比較的多い全国75箇所の歩道で調査した 結果を用いて, 歩行者密度と歩行速度の関係を分析した。 歩行速度を目的变数とし，歩行者密度を説明変数とする 回帰分析の結果, 歩行者密度が 1.0 人 $/ \mathrm{m}^{2}$ 増えると歩行速 度は0.21〜0.23 m/s遅くなった。 さらに, Polusら ${ }^{24)} は$, イスラエルのハイファに扔いて4,106名の歩行者を対象に, 歩行者密度と歩行速度の関係を分析した。歩行速度を目 的変数とし，歩行者密度を説明変数とする回帰分析の結 果，歩行者密度が 1.0 人 $/ \mathrm{m}^{2}$ 増えると歩行速度は $0.27 \mathrm{~m} / \mathrm{s}$ 遅くなった。

以上のように，歩行速度特性については道路交通分野 で詳細に研究されており, 歩行速度に影響を与える要因 についても検討されている.

ここで道路交通と踏切を比較すると, 以下のような違 いが挙げられる．まず，赤信号や踏切の遮断を予告する 際に，横断歩道では青信号が点滅するのみであるのに対 して踏切では警報が鳴動するため，急いで渡り切ろうと するといった歩行者の心理に影響を与える可能性がある. また，横断歩道では赤信号になる際に物理的な遮断はな いのに対して踏切では遮断桿が降下してくるため, 遮断 桿の降下が完了する前に通り過ぎようとするといった歩 行者の行動に影響を与える可能性がある.さらに，横断 歩道では一定間隔で青信号になるのに対して踏切では遮 断されている時間が長くなることがあるため，多数の歩 行者が一斉に横断を開始し歩行者密度が極端に高くなる 可能性がある。このような違いが歩行速度に影響を与え ることが考えられることから，道路交通分野の知見をそ のまま踏切に適用可能であるかどうかは不明である.

そこで本研究では, 踏切横断時の歩行速度に影響を与 える要因について検討するために，踏切長，鳴動状態， 混雑状態と歩行速度の平均值打よび標準偏差との関係式
を重回帰分析で推定し，それらの影響を道路交通分野の 先行研究と比較し考察した.

\section{2. 方 法}

踏切内の歩行者の実態を把握するため, 踏切長の異な る東京都内 4 箇所の踏切をビデオカメラで撮影した．撮 影にはビューポール（株式会社道路計画製）を用いた。 ビューポールとは，ポールの先端にカメラを搭載した高 所撮影システムである (図1)。踏切付近の照明柱等に設 置し高所から踏切を撮影した。 なお，踏切の撮影におい ては鉄道会社の許可を取るとともに，踏切の入口付近に 本研究の目的とデータの取り扱い等についての文書を掲 示し，倫理的な配慮を行ったうえで調査を実施した。

\section{2-1. 調査対象踏切}

多様な属性の歩行者を調査するために駅付近で交通量 の多い踏切を選定した．車道は2車線，歩道は左右両側 が色分けされている踏切とした。調查対象踏切の概要を 表1に示す.

歩行者の属性が通勤・通学者に偏らないようにラッシュ 時間帯を避け，量 (12：00〜13：00) と夕方（16：00〜

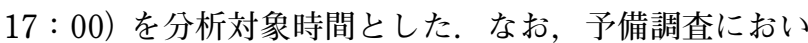
て一定時間の全歩行者の歩行速度を計測した結果，踏切 鳴動時のサンプルが少なかったので，鳴動時のサンプル

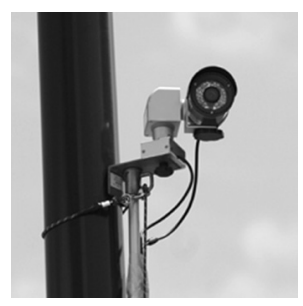

図1高所撮影システム（株式会社道路計画提供）

Fig. 1 Filming system on high place.

表1 調査対象踏切の概要と分析対象時間

Tab. 1 Outline of railroad crossing and analysis time.

\begin{tabular}{|c|c|c|c|c|}
\hline & A 踏切 & B踏切 & C踏切 & D踏切 \\
\hline 横断線数 $($ 本 & 2 & 4 & 4 & 5 \\
\hline 踏切長 $(\mathrm{m})$ & 9.2 & 13.5 & 17.0 & 24.6 \\
\hline 踏切幅 $(\mathrm{m})$ & 8.6 & 9.0 & 11,155 & 8.2 \\
\hline 交通量 $($ 人 $/$ 日) & 9,948 & 5,074 & 2015 年9月3日 (木) & 2016 年2月 25 日 (木) \\
\hline & 2016 年1月 14 日 (木) & 2016 年1月 14 日 (木) & $12: 00 \sim 13: 00$ & $12: 00 \sim 13: 00$ \\
分析対象時間 & $12: 00 \sim 13: 00$ & $12: 00 \sim 13: 00$ & $16: 00 \sim 17: 00$ & $16: 00 \sim 17: 00$ \\
& $16: 00 \sim 17: 00$ & $16: 00 \sim 17: 00$ & 鳴動時間帯 & 鳴動時間帯 \\
\hline
\end{tabular}


を増やすために上記時間帯以外で踏切が鳴動した時間を ピックアップし, その時間の歩行速度も計測した. 分析 対象時間を表1に併記した。分析対象時間の天候は晴れ もしくは曇りで, 路面は乾いた状態であった。

\section{2-2. 歩行速度の計測方法}

歩行速度については, 各歩行者が踏切に進入した時刻 と進出した時刻を記録し，その時間差と踏切長から平均 速度を算出した. 踏切内で対向歩行者等とすれ違う際に 歩行速度が大きく变化する可能性があり, 歩行速度に影 響を与える要因をより詳細に検討するためには歩行速度 の変動も考慮する必要がある. しかしながら, 本研究で は踏切横断時に打いて踏切内に滞在している時間を重視 し，多くのサンプルデータを取得するという観点から， 平均速度を用いることとした，踏切の進入 ·進出の境界 線のイメージを図 2 に示す. 図中の黒線が踏切の進入 進出の境界線を意味する。なお，自転車を降りて押して 歩いている人は歩行者として扱った.

\section{2-3. 鳴動状態の分類方法}

踏切の鳴動および遮断の状態と歩行者が踏切に進入し たタイミングとの関係を以後，単に「鳴動状態」と呼ぶ. 鳴動状態については，以下の 4 種類に分類した（表2). 踏切が鳴動する前に歩行者が踏切に進入し鳴動していな い状態で渡り終えた場合を「(1)非鳴動」, 踏切が鳴動す る前に歩行者が踏切に進入し踏切内を歩行中に鳴動した

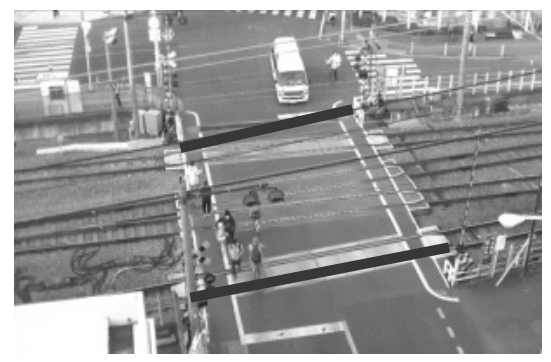

図2 踏切の進入・進出の境界線のイメージ

Fig. 2 Boundary line of entering and exiting a railroad crossing.

表2 鳴動状態の分類

Tab. 2 Classification of warning state.

\begin{tabular}{|c|c|}
\hline (1)非鳴動 & $\begin{array}{l}\text { 踏切が鳴動する前に進入し, 鳴動してい } \\
\text { ない状態で渡り終えた場合 }\end{array}$ \\
\hline (2)踏切内鳴動 & $\begin{array}{l}\text { 踏切が鳴動する前に進入し, 踏切内を歩 } \\
\text { 行中に鳴動を開始した場合 }\end{array}$ \\
\hline (3)鳴動開始後進入 & $\begin{array}{l}\text { 鳴動を開始した後で遮断桿が降下を開始 } \\
\text { する前に進入した場合 }\end{array}$ \\
\hline (4)降下開始後進入 & 遮断桿が降下を開始した後に進入した場合 \\
\hline
\end{tabular}

場合を「(2)踏切内鳴動」，鳴動を開始した後で遮断桿が 降下を開始する前に進入した場合を「(3)鳴動開始後進 入」，遮断桿が降下を開始した後に進入した場合を「(4) 降下開始後進入」とした。

\section{2-4. 混雑状態の分類方法}

ラッシュ時間帯以外でも混雑状態には差が見られ，そ の影響も分析することとした．混雑状態については，各 歩行者が踏切に進入した際の左右の歩道それぞれの歩行 者の人数を計測し，左右の歩道それぞれの面積で除して 左右の歩道それぞれの歩行者密度を算出した。なお，自 転車に乗車している人は踏切内の人数の計測に含めた.

踏切の映像から, 歩行者が混雑の影響を受ける場面と して以下の2つのパターンが観察された.

(1) 踏切に進入する際に他の歩行者の後ろに付いて歩行 する場合

(2) 逆側から横断してくる歩行者をよけながら歩行する 場合

そこで, 当該歩行者が横断する際の前半と後半の領域 の密度の高い方を採用することとした。

歩行速度の平均值と標準偏差を算出する際の各密度に おける階級の幅について，ヒストグラムの階級の幅の決 定方法の一つであるスコットの選択を用いたところ0.077 であったことから，これを参考に密度は 0.1 刻みで集計 することとした．密度の小数点第 2 位で四捨五入し，小 数点第1位までの密度を混雑状態の指標とした（例えば, 1.26 人 $/ \mathrm{m}^{2}$ は 1.3 人 $/ \mathrm{m}^{2}$ とした).

\section{2-5. 分析方法}

踏切長 (4種類), 鳴動状態 (4種類), 混雑状態 (31種 類：0.0 3.0人 $/ \mathrm{m}^{2}$ で0.1刻み) の組み合わせで計 496 条件 について，歩行速度の平均值と標準偏差を算出した．歩 行速度のばらつきの指標について, 平均值が高い条件で は標準偏差も他の条件より大きくなるので，標準偏差よ り変動係数の方が相応しい可能性がある. しかしながら, 本研究では道路交通分野の先行研究と比較するために標 準偏差を用いて検討することとした．

まず，踏切長，鳴動状態，混雑状態それぞれが歩行速 度の平均值と標準偏差に与える影響を把握するために, 単回帰分析および分散分析を行った. 目的変数は歩行速 度の平均值および標準偏差とした，説明変数はそれぞれ 踏切長の值, 鳴動状態のダミ一変数, 歩行者密度の值と した. 鳴動状態のダミ一変数は, 非鳴動を基準として,「踏 切内鳴動ダミー」,「鳴動開始後進入ダミー」,「降下開始 後進入ダミー」を用いた。 
次に, 踏切長, 鳴動状態, 混雑状態が歩行速度の平均 值と標準偏差に与える影響を明らかにするために，重回 帰分析を行った。目的変数は歩行速度の平均值打よび標 準偏差とした. 説明変数は踏切長の值, 鳴動状態のダミー 変数，歩行者密度の值とした．変数選択は増減法とし， 統計的有意水準は $5 \%$ とした。 統計解析にはエクセル統 計（株式会社社会情報サービス製）を使用した。重回帰 モデルの予測精度に関しては，回帰係数の推定に使用し ていないデータを用いて検証する必要がある。そこで, 4箇所の踏切のうち3箇所のデータで回帰係数を推定し, 残りの1箇所のデータで精度検証を行った.

\section{3. 結 果}

\section{3-1. 歩行速度計測の結果}

各踏切のサンプルサイズは, A 踏切が 3,392 名, B 踏切 が3,138名，C踏切が3,613名，D踏切が3,243名で，合計 13,386名となった。全496条件の中でサンプルが2名に満 たない条件は，平均値と標準偏差を算出できないため分 析対象から除外した。重回帰分析については，最も多く の条件で平均值と標準偏差を算出できたC踏切のデータ

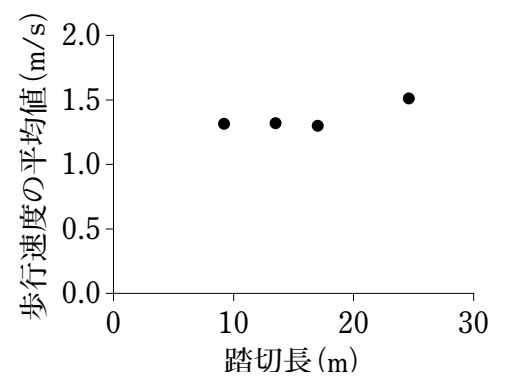

図3踏切長と歩行速度の平均值の関係

Fig. 3 Relation between length of railroad crossing and mean of walking velocity.

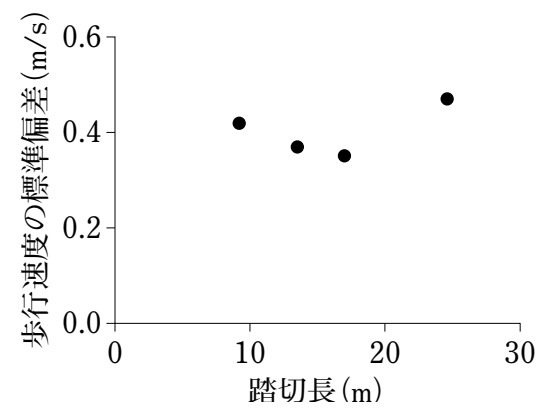

図4踏切長と歩行速度の標準偏差の関係

Fig. 4 Relation between length of railroad crossing and standard deviation of walking velocity.
を精度検証用とし，残りの3箇所の踏切のデータで回帰 係数を推定することとした。

\section{3-2. 単回帰分析および分散分析の結果}

\section{3-2-1． 踏切長が歩行速度に与える影響}

踏切長と歩行速度の平均值の関係を図 3 に, 踏切長と 歩行速度の標準偏差の関係を図4に示す，歩行速度の平 均值を目的変数とし，踏切長を説明変数とした単回帰分 析の結果を表 $3 に$ 示す．調整済み決定係数は $\mathrm{R}^{2}=0.562 て ゙$ 有意でなかった $(p=0.158)$ ，歩行速度の標準偏差を目 的変数とし，踏切長を説明変数とした単回帰分析の結果 を表 4 に示す，調整済み決定係数は $\mathrm{R}^{2}=0.228 て ゙$ 有意でな かった $(p=0.523)$.

\section{3-2-2. 鳴動状態が歩行速度に与える影響}

鳴動状態と歩行速度の平均值の関係を図5に示す。図5 のエラーバーは標準誤差を示す。鳴動状態の4群を説明 変数とし，それぞれの歩行速度の平均值を目的変数とし て一要因分散分析を行った。その結果，有意な主効果が 見られ $(F(3,13382)=884.97, p<0.05)$, Bonferroni法 による多重比較の結果，4降下開始後進入は他の3群よ り歩行速度が有意に速く，(3)鳴動開始後進入は(2)踏切内 鳴動打よび(1)非鳴動より歩行速度が有意に速かった。

鳴動状態と歩行速度の標準偏差の関係を図6に示す。 鳴動状態の4群において，分散が等しいかについてル

表3 歩行速度の平均値を目的変数，踏切長を説明変数とし た単回帰分析の結果

Tab. 3 Result of simple linear regression analysis (objective variable: mean of walking velocity, explanatory variable: length of railroad crossing).

\begin{tabular}{|c|c|c|c|}
\hline \multicolumn{2}{|c|}{ 変数 } & 踏切長 & 定数項 \\
\hline \multicolumn{2}{|c|}{ 回帰係数 } & 0.013 & 1.150 \\
\hline \multicolumn{2}{|c|}{ 標準誤差 } & 0.006 & 0.101 \\
\hline \multirow{2}{*}{ 回帰係数の } & 上限值 & 0.039 & 1.584 \\
\cline { 2 - 4 } $95 \%$ 信頼区間 & 下限值 & -0.012 & 0.716 \\
\hline \multicolumn{2}{|c|}{$p$ 值 } & 0.158 & $p<0.05$ \\
\hline
\end{tabular}

表4 歩行速度の標準偏差を目的变数, 踏切長を説明变数と した単回帰分析の結果

Tab. 4 Result of simple linear regression analysis (objective variable: standard deviation of walking velocity, explanatory variable: length of railroad crossing).

\begin{tabular}{|c|c|c|c|}
\hline \multicolumn{2}{|c|}{ 変数 } & 踏切長 & 定数項 \\
\hline \multicolumn{2}{|c|}{ 回帰係数 } & 0.004 & 0.339 \\
\hline \multicolumn{2}{|c|}{ 標準䛊差 } & 0.005 & 0.087 \\
\hline \multirow{2}{*}{$\begin{array}{c}\text { 回帰係数の } \\
95 \% \text { 信頼区間 }\end{array}$} & 上限值 & 0.026 & 0.713 \\
\hline & 下限值 & -0.018 & -0.035 \\
\hline \multicolumn{2}{|l|}{ p值 } & 0.523 & 0.060 \\
\hline
\end{tabular}




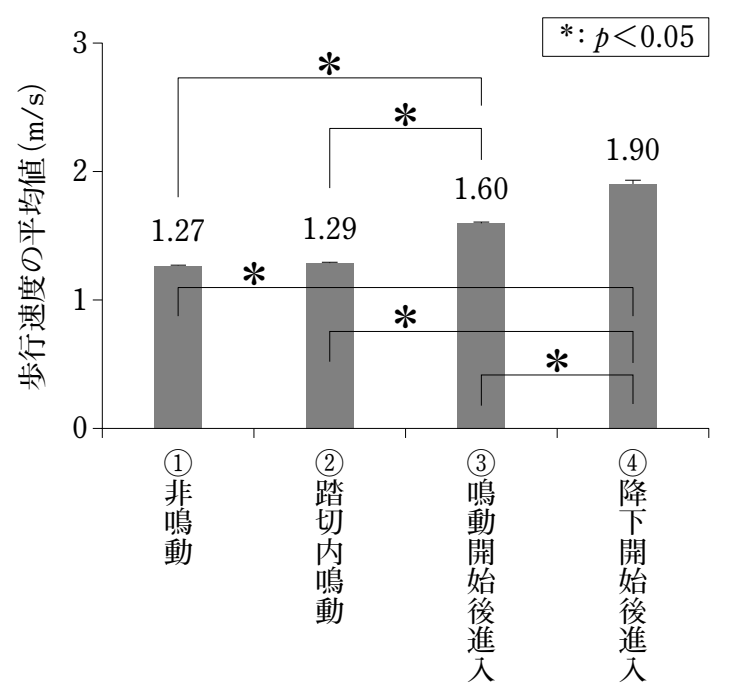

図5鳴動状態と歩行速度の平均值の関係

Fig. 5 Relation between warning of railroad crossing and mean of walking velocity.

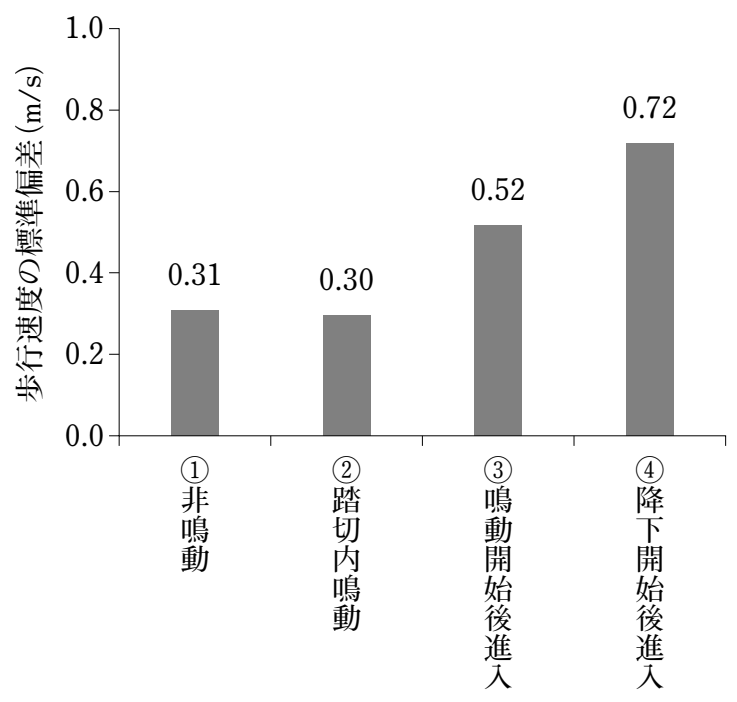

図6鳴動状態と歩行速度の標準偏差の関係

Fig. 6 Relation between warning of railroad crossing and standard deviation of walking velocity.

ビーン検定を行った。その結果，群間に有意差が見られ $(F(3,13382)=575.64, p<0.05)$, (1)非鳴動から (4)降下 開始後進入へ踏切の遮断が進むにつれて歩行速度の標準 偏差が大きくなる傾向であった。

\section{3-2-3．混雑状態が歩行速度に与える影響}

密度と歩行速度の平均值の関係を図7に, 密度と歩行 速度の標準偏差の関係を図8に示す，歩行速度の平均值 を目的変数とし，密度を説明変数とした単回帰分析の 結果を表5に示す。調整済み決定係数は $\mathrm{R}^{2}=0.674$ で有 意であった $(p<0.05)$. 回帰係数より, 踏切内の密度が 1.0 人 $/ \mathrm{m}^{2}$ 高くなると，歩行速度の平均值は $0.132 \mathrm{~m} / \mathrm{s}$ 遅く なった，歩行速度の標準偏差を目的変数とし，密度を説

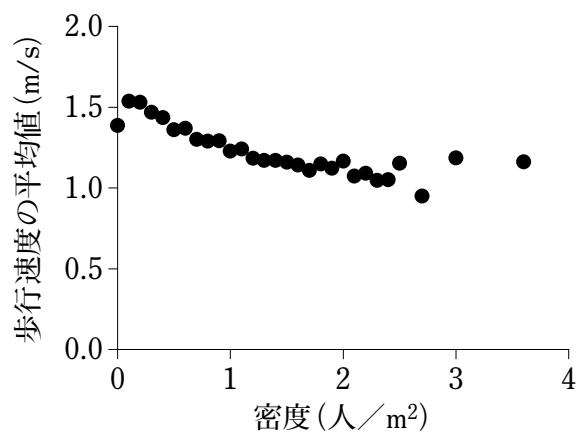

図7 密度と歩行速度の平均值の関係

Fig. 7 Relation between congestion of railroad crossing and mean of walking velocity.

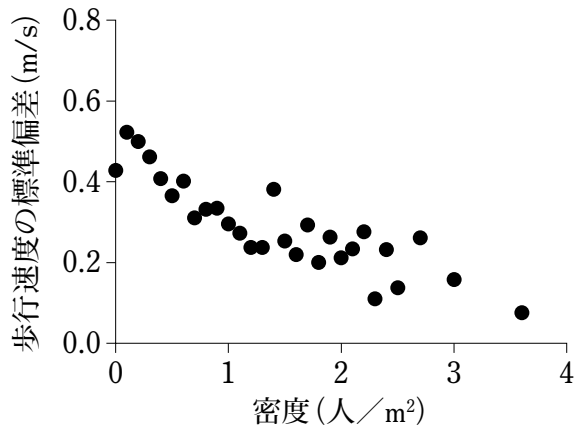

図8＼cjkstart密度と歩行速度の標準偏差の関係

Fig. 8 Relation between congestion of railroad crossing and standard deviation of walking velocity.

表5 歩行速度の平均值を目的変数，密度を説明変数とした 単回帰分析の結果

Tab. 5 Result of simple linear regression analysis (objective variable: mean of walking velocity, explanatory variable: congestion of railroad crossing).

\begin{tabular}{|c|c|c|c|}
\hline \multicolumn{2}{|l|}{ 変数 } & 密度 & 定数項 \\
\hline \multicolumn{2}{|c|}{ 回帰係数 } & -0.132 & 1.415 \\
\hline \multicolumn{2}{|c|}{ 標準誤差 } & 0.017 & 0.029 \\
\hline \multirow{2}{*}{$\begin{array}{c}\text { 回帰係数の } \\
95 \% \text { 信頼区間 }\end{array}$} & 上限值 & -0.097 & 1.476 \\
\hline & 下限值 & -0.167 & 1.355 \\
\hline \multicolumn{2}{|l|}{$p$ 值 } & $p<0.05$ & $p<0.05$ \\
\hline
\end{tabular}

表6 歩行速度の標準偏差を目的変数, 密度を説明変数とし た単回帰分析の結果

Tab. 6 Result of simple linear regression analysis (objective variable: standard deviation of walking velocity, explanatory variable: congestion of railroad crossing).

\begin{tabular}{|c|c|c|c|}
\hline \multicolumn{2}{|c|}{ 変数 } & 密度 & 定数項 \\
\hline \multicolumn{2}{|c|}{ 回帰係数 } & -0.104 & 0.441 \\
\hline \multicolumn{2}{|c|}{ 標準誤差 } & 0.011 & 0.019 \\
\hline \multirow{2}{*}{ 回帰係数の } & 上限值 & -0.081 & 0.480 \\
\cline { 2 - 4 } $95 \%$ 信頼区間 & 下限值 & -0.127 & 0.401 \\
\hline \multicolumn{2}{|c|}{$p$ p值 } & $p<0.05$ & $p<0.05$ \\
\hline
\end{tabular}


表7 歩行速度の平均值を目的変数とした重回帰分析の結果

Tab. 7 Result of multiple regression analysis (objective variable: mean of walking velocity).

\begin{tabular}{|c|c|c|c|c|c|c|}
\hline \multirow{2}{*}{ 変数 } & \multirow{2}{*}{ 偏回帰係数 } & \multirow{2}{*}{ 標準誤差 } & \multirow{2}{*}{ 標準偏回帰係数 } & \multicolumn{2}{|c|}{ 偏回帰係数の95\%信頼区間 } & \multirow{2}{*}{$p$ 值 } \\
\hline & & & & 下限值 & 上限值 & \\
\hline 踏切長 (m) & 0.006 & 0.002 & 0.125 & 0.001 & 0.011 & $p<0.05$ \\
\hline 踏切内鳴動ダミー & -0.073 & 0.038 & -0.097 & -0.149 & 0.003 & 0.059 \\
\hline 鳴動開始後進入ダミー & 0.256 & 0.038 & 0.341 & 0.180 & 0.332 & $p<0.05$ \\
\hline 降下開始後進入ダミー & 0.541 & 0.047 & 0.569 & 0.448 & 0.634 & $p<0.05$ \\
\hline 密度 $($ 人/m²) & -0.224 & 0.026 & -0.426 & -0.277 & -0.172 & $p<0.05$ \\
\hline 定数項 & 1.386 & 0.061 & & 1.265 & 1.506 & $p<0.05$ \\
\hline
\end{tabular}

表8 歩行速度の標準偏差を目的変数とした重回帰分析の結果

Tab. 8 Result of multiple regression analysis (objective variable: standard deviation of walking velocity).

\begin{tabular}{|c|c|c|c|c|c|c|}
\hline \multirow{2}{*}{ 変数 } & \multirow{2}{*}{ 偏回帰係数 } & \multirow{2}{*}{ 標準誤差 } & \multirow{2}{*}{ 標準偏回帰係数 } & \multicolumn{2}{|c|}{ 偏回帰係数の95\% 信頼区間 } & \multirow{2}{*}{$p$ 值 } \\
\hline & & & & 下限值 & 上限值 & \\
\hline 踏切内鳴動ダミー & -0.080 & 0.029 & -0.175 & -0.138 & -0.021 & $p<0.05$ \\
\hline 鳴動開始後進入ダミー & 0.092 & 0.029 & 0.203 & 0.034 & 0.150 & $p<0.05$ \\
\hline 降下開始後進入ダミー & 0.220 & 0.036 & 0.383 & 0.149 & 0.292 & $p<0.05$ \\
\hline 密度 $($ 人/m²) & -0.159 & 0.018 & -0.500 & -0.195 & -0.123 & $p<0.05$ \\
\hline 定数項 & 0.442 & 0.027 & & 0.388 & 0.496 & $p<0.05$ \\
\hline
\end{tabular}

明変数とした単回帰分析の結果を表 $6 に$ 示す。調整済み 決定係数は $\mathrm{R}^{2}=0.754$ で有意であった $(p<0.05)$. 回帰係 数より, 踏切内の密度が 1.0 人 $/ \mathrm{m}^{2}$ 高くなると, 歩行速度 の標準偏差は $0.104 \mathrm{~m} / \mathrm{s}$ 小さくなった.

\section{3-3. 重回帰分析の結果}

\section{3-3-1. 歩行速度の平均値に対する重回帰モデル}

歩行速度の平均值を目的変数とした重回帰分析の結 果を表7に示す. 調整済み決定係数は $\mathrm{R}^{2}=0.695$ で有意で あった $(p<0.05) . p$ 值から統計的に有意な説明変数は, 踏切長, 鳴動開始後進入ダミ一, 降下開始後進入ダミー, 密度であった. 偏回帰係数より, 以下のように整理できる.

·他の変数を一定にした場合, 踏切長が $1 \mathrm{~m}$ 長くなると, 歩行速度の平均值は $0.006 \mathrm{~m} / \mathrm{s}$ 速くなる.

・他の変数を一定にした場合, 踏切を渡りきるまで鳴動 しない状態と比較して, 鳴動を開始した後で遮断桿が 降下を開始する前に踏切に進入すると, 歩行速度の平 均値は $0.256 \mathrm{~m} / \mathrm{s}$ 速くなる.

・他の変数を一定にした場合, 踏切を渡りきるまで鳴動 しない状態と比較して, 遮断桿が降下を開始した後に 踏切に進入すると, 歩行速度の平均值は $0.541 \mathrm{~m} / \mathrm{s}$ 速く なる。

・他の変数を一定にした場合, 踏切内の密度が 1.0 人 $/ \mathrm{m}^{2}$ 高くなると, 歩行速度の平均值は $0.224 \mathrm{~m} / \mathrm{s}$ 遅くなる.

また，標準偏回帰係数より，これら4変数の中で遮断

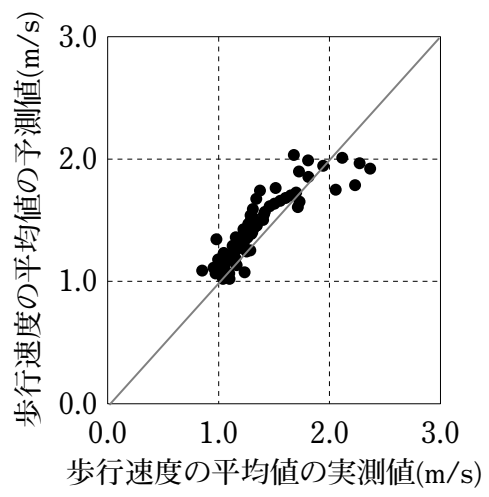

図9 C踏切における歩行速度の平均值の実測值と予測值

Fig. 9 Actual and predictive values of mean of walking velocity at railroad crossing $\mathrm{C}$.

桿が降下を開始した後に進入することの影響が最も大き かった.

回帰係数の推定に使用していないC 踏切における歩行 速度の平均值の実測值と予測值を比較したものを図9に 示す. 歩行速度の平均值は実測值と予測值がよく一致し ており，高い精度で予測できていることが確認できる. 予測䛊差は平均で $0.175 \mathrm{~m} / \mathrm{s}$, 最大で $0.445 \mathrm{~m} / \mathrm{s}$ であった.

\section{3-3-2. 歩行速度の標準偏差に対する重回帰モデル}

歩行速度の標準偏差を目的変数とした重回帰分析の結 果を表 8 に示す。調整済み決定係数は $\mathrm{R}^{2}=0.512$ で有意で あった $(p<0.05)$. $p$ 值から統計的に有意な説明変数は, 踏切内鳴動ダミ一, 鳴動開始後進入ダミ一, 降下開始後 


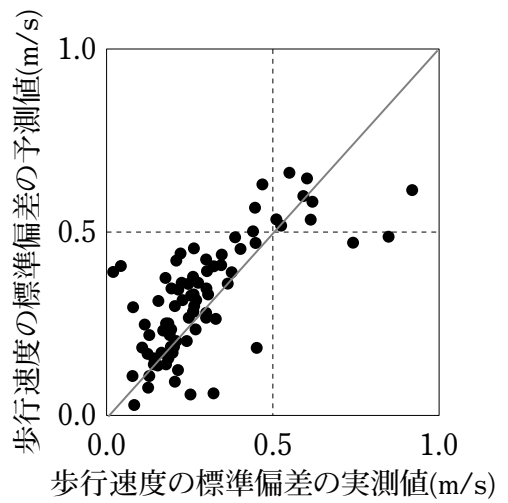

図10 C 踏切における歩行速度の標準偏差の実測值と予測值

Fig. 10 Actual and predictive values of standard deviation of walking velocity at railroad crossing $\mathrm{C}$.

進入ダミー，密度であった。偏回帰係数より，以下のよ うに整理できる。

・他の変数を一定にした場合, 踏切を渡りきるまで鳴動 しない状態と比較して, 踏切内を歩行中に鳴動すると, 歩行速度の標準偏差は $0.080 \mathrm{~m} / \mathrm{s}$ 小さくなる.

・他の変数を一定にした場合, 踏切を渡りきるまで鳴動 しない状態と比較して, 鳴動を開始した後で遮断桿が 降下を開始する前に踏切に進入すると，歩行速度の標 準偏差は $0.092 \mathrm{~m} / \mathrm{s}$ 大きくなる.

・他の変数を一定にした場合, 踏切を渡りきるまで鳴動 しない状態と比較して，遮断桿が降下を開始した後に 踏切に進入すると，歩行速度の標準偏差は $0.220 \mathrm{~m} / \mathrm{s}$ 大 きくなる.

·他の変数を一定にした場合, 踏切内の密度が 1.0 人 $/ \mathrm{m}^{2}$ 高くなると，歩行速度の標準偏差は $0.159 \mathrm{~m} / \mathrm{s}$ 小さく なる.

また，標準偏回帰係数より，これら4变数の中で密度 の影響が最も大きかった。

回帰係数の推定に使用していないC踏切に打ける歩行 速度の標準偏差の実測值と予測值を比較したものを図 10 に示す．歩行速度の標準偏差は実測值と予測值がよく一 致しており，高い精度で予測できていることが確認できる. 予測䛊差は平均で $0.128 \mathrm{~m} / \mathrm{s}$ ，最大で $0.373 \mathrm{~m} / \mathrm{s}$ であった。

\section{4. 考 察}

単回帰分析および分散分析，重回帰分析の結果のまと めを表9に示す．まず，踏切長の影響について，踏切長 が長くなると歩行速度の平均值は有意に速くなった。ま た，鳴動状態の影響について，遮断が進むにつれて歩行 速度の平均值は有意に速くなり，標準偏差は有意に大き
表9 単回帰分析および分散分析，重回帰分析の結果のまとめ

Tab. 9 Summary of simple linear regression analysis, analysis of variance, and multiple regression analysis.

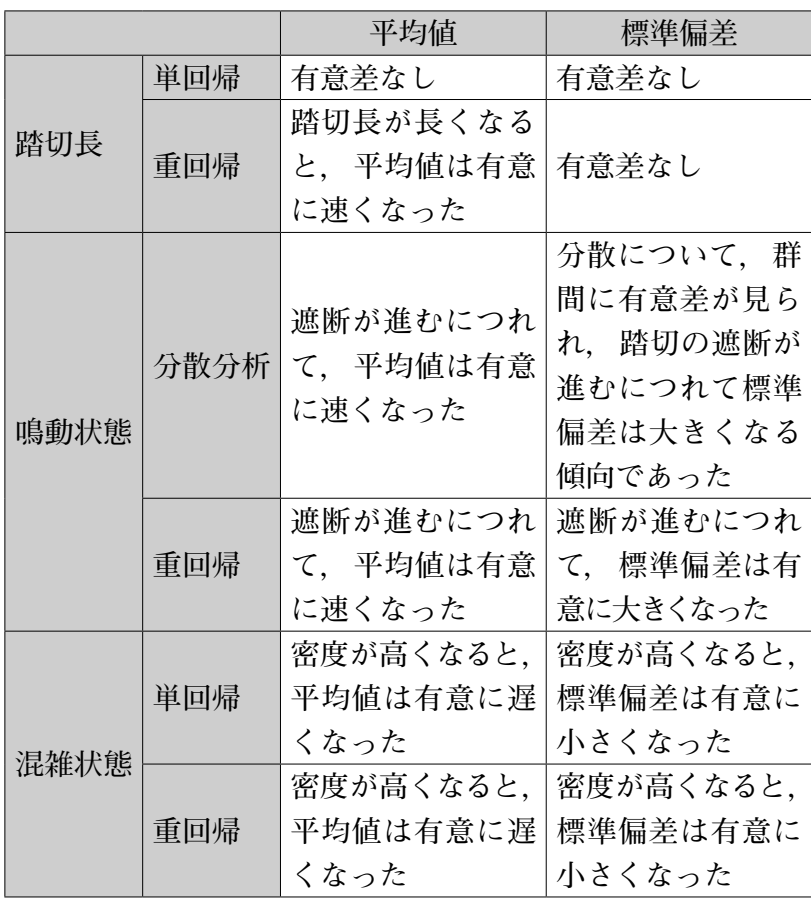

くなった。さらに，混雑状態の影響について，密度が高 くなると歩行速度の平均值は有意に遅くなり，標準偏差 は有意に小さくなった。

\section{4-1. 踏切長が歩行速度に与える影響について}

道路交通における先行研究17)では，横断歩道における 平均歩行速度は横断歩道長の増加に伴い速くなると報告 されている. 本研究における単回帰分析の結果，歩行速 度の平均值に対する踏切長の影響は有意ではなかった。 その理由として，各踏切に打ける踏切長以外の要因の影 響が考えられる．表1の調査対象踏切の概要を見ると，A 踏切の踏切長が他の踏切よりも短いこと, C踏切の歩行 者交通量が他の踏切よりも多いことが特徵として挙げら れる．短い踏切では鳴動を開始した後や遮断桿が降下を 開始した後に進入する歩行者が比較的多いと考えられ， その結果，鳴動状態の違いを考慮せずに歩行速度の平均 值を算出すると，短い踏切ほど歩行速度の平均值が高く なる可能性がある。 また，歩行者の交通量が多い踏切で は歩行者の密度が高い時間が比較的長いと考えられ，そ の結果，混雑状態を考慮せずに歩行速度の平均值を算出 すると，歩行者の交通量が多い踏切ほど歩行速度の平均 值が遅くなる可能性がある.

道路交通に打ける先行研究 ${ }^{17)}$ では，横断歩道長が $5 \mathrm{~m}$ 長くなると，歩行速度の平均値は概ね $0.05 \mathrm{~m} / \mathrm{s}$ 速くなる と報告されている。本研究における重回帰分析の結果， 
歩行速度の平均值に対する踏切長の偏回帰係数は 0.006

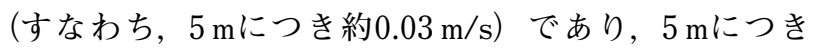
$0.05 \mathrm{~m} / \mathrm{s}$ よりや低いが概ね同様の傾向であった. 重回 帰分析により, 踏切長以外の要因の影響が調整されたた め，横断歩道長と同様の傾向が示されたと考えられる.

踏切長が歩行速度の標準偏差に与える影響について, 単回帰分析と重回帰分析ともに有意ではなかった。単回 帰分析で有意ではなかった理由としては，平均值の場合 と同様に各踏切における踏切長以外の要因の影響が考え られる。また，重回帰分析で有意ではなかった理由とし ては, 踏切長が歩行速度に与える影響が他の要因に比べ て相対的に小さいことが考えられる. 表7の標準偏回帰

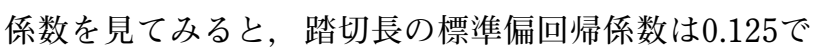
あり，絶対値の大きさは他の要因の半分以下であった. このように踏切長の影響が相対的に小さいため, 歩行速 度の標準偏差において有意差を検出できなかった可能性 がある. 踏切長が歩行速度に与える影響について詳細に 検討するためには, 調查対象踏切の数を増やす等, 別途 検討が必要である.

\section{4-2. 鳴動状態が歩行速度に与える影響について}

道路交通における先行研究18) は，青信号点滅後に横断 を開始した歩行者は青信号点灯中に横断を開始した歩行 者より速度が速くばらつきが大きいことを指摘している.

本研究に打ける分散分析の結果，踏切が鳴動を開始し た後に進入した場合は，鳴動を開始する前に進入した場 合と比較して, 歩行速度の平均值は有意に速く, 標準偏 差は大きい傾向であった。 また，重回帰分析の結果，歩 行速度の平均值に対する鳴動開始後進入ダミ一の偏回 帰係数は 0.256 , 降下開始後進入ダミーの偏回帰係数は 0.541であり, 歩行速度の標準偏差に対する鳴動開始後 進入ダミーの偏回帰係数は 0.092 , 降下開始後進入ダミー の偏回帰係数は 0.220 であった，踏切に打いても鳴動開 始後に進入した場合，歩行速度は速くばらつきは大きく なった. 横断歩道と踏切のどちらも渡りきるための制限 時間が少ないことを知らされて，歩行速度を上げたため と考えられる. これらの知見は, 踏切横断時の歩行速度 を考虑した鳴動時間の設定について検討する際に役立つ と考えられる。

一方で，ばらつきが大きくなったことから，歩行速度 を上げる歩行者と上げない（あるいは，上げられない） 歩行者がいるものと考えられる. 高齢者の歩行速度に 関する先行研究4) では, 性別, 年代別の標準歩行速度 および最高歩行速度が報告されている，例えば，男性 の40歳代において標準歩行速度は平均 $1.46 \mathrm{~m} / \mathrm{s}$ （標準偏
差 $0.16 \mathrm{~m} / \mathrm{s}$ )，最高歩行速度は平均 $2.46 \mathrm{~m} / \mathrm{s}$ （標準偏差 $0.36 \mathrm{~m} / \mathrm{s})$ であり, 最高歩行速度は標準歩行速度の 1.68 倍 であった。一方，男性の70歳代では標準歩行速度は平 均 $1.33 \mathrm{~m} / \mathrm{s}$ （標準偏差 $0.20 \mathrm{~m} / \mathrm{s}$ ), 最高歩行速度は平均 $2.08 \mathrm{~m} / \mathrm{s}$ （標準偏差 $0.36 \mathrm{~m} / \mathrm{s}$ ) であり，最高歩行速度は標 準歩行速度の1.56倍となり，70歳代の方が最高歩行速度 で速くなる割合が低かった。このことから，鳴動を開始 した後に進入した場合でも若年者ほど歩行速度を上げら れない高齢者等がおり，ばらつきが大きくなった可能性 がある、しかしながら本研究においては，ビデオ観察で あったことから歩行者の年齢を正確に知ることはできな い. 踏切横断に打ける年齢と歩行速度の関係については, 歩行者の年齢を聞き取る等，別途検討が必要である.

また，道路交通における先行研究19) では，残りの横断 距離が長くない場合，横断途中で信号が青信号点滅に切 り替わっても歩行速度はあまり上昇しないと報告されて いる. 本研究の重回帰分析に扔いても, 踏切内鳴動ダミー は有意な変数として選択されなかった。一方で，先行研 究19)では, 信号切り替わり後の残りの横断距離が $20 \mathrm{~m}$ 超えるような長い場合に打いては，歩行速度は上昇する 傾向があったと報告されている. 踏切長と鳴動タイミン グの交互作用についてはさらなる検討が必要である.

\section{4-3. 混雑状態が歩行速度に与える影響について}

道路交通における先行研究22)において，歩行者密度が 1.5 人 $/ \mathrm{m}^{2}$ までは密度が増加すると歩行速度は直線的に低 下していき，密度が 1.5 人 $/ \mathrm{m}^{2}$ 以上になると歩行速度は一 旦急激に低下寸るが，その後また緩やかに低下していく と報告されている.

本研究に抢ける単回帰分析の結果，歩行速度の平均值 および標準偏差に対する歩行者密度の影響は有意であっ たが，平均值と標準偏差ともに線形モデルで近似できる のは歩行者密度が 1.5 人 $/ \mathrm{m}^{2}$ 付近までであると読み取れる (図7，図8)。密度が 1.5 人 $/ \mathrm{m}^{2}$ 以上では，平均值と標準偏 差ともに減少の度合いが緩やかになる傾向であり，各歩 行者が自らの歩行速度を自由に決められなくなり歩行者 が群化することを示唆している.

単回帰分析の結果から，密度が 1.5 人 $/ \mathrm{m}^{2}$ 以上を含めて 線形モデルで近似することは相応しくない可能性がある が，本研究では道路交通分野の先行研究と比較するため に重回帰分析を用いて検討した，道路交通における先行 研究22 24)では，歩行者密度が 1.0 人 $/ \mathrm{m}^{2}$ 増えるごとに歩行 速度は $0.20 \sim 0.27 \mathrm{~m} / \mathrm{s}$ 遅くなると報告されている．本研 究においては, 踏切内の密度が 1.0 人 $/ \mathrm{m}^{2}$ 増えると, 歩行 速度の平均值が $0.224 \mathrm{~m} / \mathrm{s}$ 遅くなるという結果となり，先 
行研究と同程度であった。これらの知見は，歩行者の横 断行動を考慮した踏切内の歩道幅について検討する際に 役立つと考えられる。

\section{4-4. 本研究の限界について}

3箇所の踏切で計測した歩行速度のデータから推定し た重回帰モデルの妥当性が確認されたが, 本研究の限界 として, 踏切の属性, 測定方法, サンプルに関する課題 が挙げられる.

第一に, 本研究で調查対象とした踏切の長さが限定的 であったため，踏切長の適用範囲は9.2 24.6 mである. この範囲外の踏切長においては本研究と同様の方法で データを取得し，回帰係数を推定する必要がある。また， 踏切遮断の条件について, 左右両側から遮断する踏切を 対象としたが，片側から遮断する踏切や遮断桿がない踏 切での妥当性に関しては，別途検討する必要がある．さ らに，車道の両側に歩道が設けられている踏切のみを対 象としたことが挙げられる。皇れゆえ片側に歩道がない， もしくは両側に歩道がない踏切での妥当性に関しては, 別途検討が必要である.

第二に, 測定方法については歩行速度と歩行者密度の 課題が挙げられる. 本研究では歩行者は踏切内を一定速 度で歩行していると仮定して, 歩行速度の変動は考慮し ていない，歩行速度の変動に影響を与える要因を明らか にするためには，歩行速度の時間変化について検討する 必要がある，例えば，歩行中に側方を自動車や自動二輪 車が通過することにより歩行速度が影響を受ける可能性 がある．通過車両が歩行速度に与える影響については， 別途検討が必要である. また, 歩行者密度について, 線 形モデルを適用できる範囲は密度が 1.5 人 $/ \mathrm{m}^{2}$ 付近までで ある可能性があり, 密度が 1.5 人 $/ \mathrm{m}^{2}$ 以上を含めた詳細な 分析に関しては非線形モデル等を用いた検討が必要であ る.さらに, 遮断桿が上がった直後は, 進入待ちをして いた歩行者や自転車が一斉に進入するため，歩道からは み出して歩く人もいるので, 歩道の面積で割ると実際よ りも密度が高い可能性がある. 正確な密度を算出するた めには，各歩行者の時系列の位置を計測し時系列の密度 を算出する等の検討が必要である.

最後に, サンプルに関する限界について, 予備調査に おいて一定時間の全歩行者の歩行速度を計測した結果， 踏切鳴動時のサンプルが少なかったので，本研究では鳴 動時のサンプルを増やすために踏切が鳴動した時間をピッ クアップし，その時間の歩行速度も計測した。このよう な計測方法でも, 鳴動状態の分類のうち, (3)鳴動開始後 進入と (4)降下開始後進入で横断をする人は少なく, サン
プルが少ない条件があった，データ数が少ないと平均值 や標準偏差は安定しない可能性があるので，安定した結 果を得るためには踏切鳴動時のサンプルをさらに増やし た検討が必要である.また, 季節の影響について，A，B， D踏切は冬にデータを収集し，C踏切は秋ごろに収集し た. 身体活動量や歩行速度は気温に左右される可能性が あることから，季節の影響については別途検討が必要で ある。

\section{5. おわりに}

本研究では, 踏切長, 鳴動状態, 混雑状態が踏切横断 時の歩行速度の平均值と標準偏差に与える影響について 検討した．歩行速度の平均值抢よび標準偏差を目的変数 として, 踏切長, 鳴動状態, 混雑状態を説明変数とした 重回帰分析の結果，下記の知見が明らかになった.

·3箇所の踏切のデータをもとに推定した重回帰モデル で算出した歩行速度の平均值と標準偏差は実測值とよ く一致した．また，重回帰モデルの推定に使用してい ない1箇所の踏切における歩行速度の平均値と標準偏 差をよく説明できるものであった。

・歩行速度の平均值に影響を与える变数は, 踏切長, 鳴 動開始後進入ダミー，降下開始後進入ダミ一，密度で あった。これら4変数の中で遮断桿が降下を開始した 後に進入することの影響が最も大きく，他の変数を一 定にした場合，踏切を渡りきるまで鳴動しない状態と 比較して，遮断桿が降下を開始した後に踏切に進入す ると，歩行速度の平均值は $0.541 \mathrm{~m} / \mathrm{s}$ 速くなった。

・歩行速度の標準偏差に影響を与える変数は, 踏切内鳴 動ダミ一, 鳴動開始後進入ダミー, 降下開始後進入ダ ミ一，密度であった。これら4変数の中で踏切内の密 度の影響が最も大きく，他の変数を一定にした場合， 密度が 1.0 人 $/ \mathrm{m}^{2}$ 高くなると, 歩行速度の標準偏差は $0.159 \mathrm{~m} / \mathrm{s}$ 小さくなった.

\section{謝 辞}

踏切の撮影においては，西武鉄道株式会社の関係者の 皆様に多大なご協力を頂いた。ここに記して感謝の意を 表す.

\section{文 献}

1）国土交通省 高齢者等による踏切事故防止対策検討会. 高齢者等の踏切事故防止対策について. 2015.

2）溝端光雄. 高齢ドライバーと高齢歩行者の交通特性につ いて. IATSS Review. 1990, 16 (1), p.49-57.

3) Lord, S.R.; Lloyd, D.G.; et al. Sensorimotor function, 
gait patterns and falls in community-dwelling women. Age and Ageing. 1996, 25, p.292-299.

4) Bohannon, R.W. Comfortable and maximum walking speed of adults aged 20 to 79 years: Reference values and determinants. Age and Ageing. 1997, 26, p.15-19.

5）佐藤稔久, 赤松幹之, 他. 踏み切り前での一旦停止義務解 除時における踏切内での停滞可能性の評価. 自動車技術会 論文集. 2008, 39 (6), p.259-264.

6）佐藤稔久, 赤松幹之, 他. 踏切前での一旦停止義務解除時 における踏切内での停滞可能性の評価（第2報）一徐行時 での停滞可能性と先々行車による影響一. 自動車技術会論 文集. 2010, 41 (4), p.933-939.

7）松本真吾, 羽山和紀, 他. 踏切直前での警報開始に対する ドライバーの運転行動評価. 鉄道総研報告. 2010, 24 (11), p.11-16.

8) Tenkink, E.; Van der Horst, R. Car driver behavior at flashing light railroad grade crossings. Accident Analysis and Prevention. 1990, 22 (3), p.229-239.

9) Lenné, M.G.; Rudin-Brown, C.M.; et al. Driver behaviour at rail level crossings: Responses to flashing lights, traffic signals and stop signs in simulated rural driving. Applied Ergonomics. 2011, 42, p.548-554.

10）福田宇志. 踏切における歩行者・自転車利用者のリスク テイキング行動ー警告時間の影響一. 労働科学. 2008,84 (4), p.140-150.

11) Lobb, B.; Harre, N.; et al. An evaluation of a suburban railway pedestrian crossing safety programme. Accident Analysis and Prevention. 2001, 33 (2), p.157-165.

12) Khattak, A.; Luo, Z. Pedestrian and bicyclist violations at highway-rail grade crossings. Transportation Research Record. 2011, 2250, p.76-82.

13）鈴木大輔, 遠藤広晴, 他. 踏切鳴動を考慮した踏切通行者 の歩行速度. 人間工学. 三重市, 2016-06-25/26. 日本人間 工学会, 2016, p.308-309.

14）鈴木大輔, 遠藤広晴, 他. 踏切の鳴動状態と混雑状態を 考慮した通行者の歩行速度. 人間工学. 習志野市, 2017-0601/04. 日本人間工学会, 2017, p.302-303.

15）交通工学研究会編. 交通工学ハンドブック. 技法堂出版, 1984, p.90-96.

16) Institute of Transportation Engineers. Transportation and Traffic Engineering Handbook. PRENTICE-HALL, INC. 1976, p.58-59.

17）斉藤威, 有哣卓. 信号交差点における横断歩行者の歩行 速度に関する基本的な特性. 科学警察研究所報告（交通 編). 1986, 27 (1), p.15-27.

18）張馨, 中村英樹, 他. 横断歩道長と歩行者信号現示を考 慮した横断歩行速度のモデル化. 土木学会論文集D3（土 木計画学). 2014, 70 (5), p.I_1031-I_1040.

19）矢野伸裕. 信号機付き横断歩道における歩行者の横断速 度に関する研究 (1. 信号表示の切り替わり前後での横断 速度の比較). 科学警察研究所報告 (交通編). 2001, 41 (2), p.22-37.
20）矢野伸裕. 信号機付き横断歩道における歩行者の横断速 度に関する研究 (2. 横断開始タイミングと横断速度の関 係)。科学警察研究所報告 (交通編). 2005, 44 (1), p.38-43.

21) Lam, W.H.K.; Cheung, C. Pedestrian speed/flow relationships for walking facilities in Hong Kong. Journal of Transportation Engineering. 2000, 126 (4), p.343-349.

22）毛利正光, 塚口博司. 歩行路における歩行者挙動に関す る研究. 土木学会論文報告集. 1977, 268, p.99-108.

23）高宮進，森望. 歩行者交通流からみた歩道幅員に関する 一考察. 土木技術資料. 2002, 44 (9), p.109-114.

24) Polus, A.; Schofer, J.L.; et al. Pedestrian flow and level of service. Journal of Transportation Engineering. 1983, 109 (1), p.46-56.

\section{著者情報}

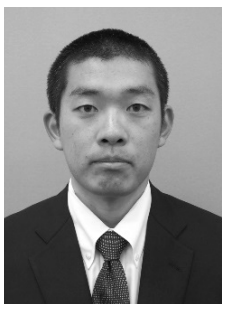

鈴木大輔（すずきだいすけ，正会員，連絡 著者)

2009年慶應義塾大学大学院理工学研究科 開放環境科学専攻博士課程修了。博士（工 学)．(公財) 鉄道総合技術研究所勤務．専 門領域：安全人間工学，ヒューマンファク ターズほか. 日本人間工学会, 安全工学会, 日本プラント・ヒューマンファクター学会, 日本鉄道運転協会会員ほか.

連絡先：suzuki.daisuke.55@rtri.or.jp

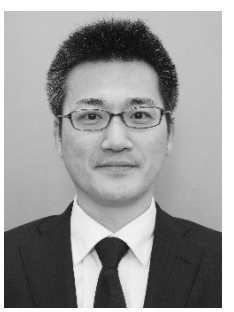

遠藤広晴（えんどうひろはる，正会員） 2004年慶應義塾大学大学院理工学研究科 基礎理工学専攻修士課程修了。（公財）鉄 道総合技術研究所勤務. 専門領域：人間工 学. 日本人間工学会，人間－生活環境系学 会会員.

斎藤綾乃（さいとうあやの，正会員）

1996年千葉大学大学院工学研究科工業意匠学専攻修了. 博士 (工学). (公財) 鉄道総合技術研究所勤務. 専門領域 : 人間工 学ほか.

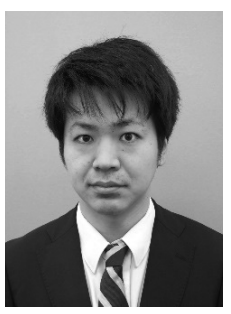

秋保直弘（あきうなおひろ）

2012年東北大学大学院工学研究科量子工 ネルギー工学専攻博士前期課程修了. 修士 (工学). (公財) 鉄道総合技術研究所勤務. 専門領域：人間工学，ヒューマンインタ フェースほか. ヒューマンインタフェース 学会会員ほか.

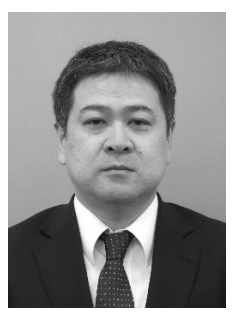

水上直樹（みずかみなおき，正会員） 1993年北里大学大学院衛生学研究科修士 課程修了，修士 (衛生学)。(公財) 鉄道総 合技術研究所勤務. 専門領域 : 人間工学 (疲 労，バリアフリーほか). 日本人間工学会, 日本交通医学会，日本福祉のまちづくり学 会会員ほか. 